\title{
Timing of Onset of Volcanic Centers in the Campanian of Western North America as Determined by Distal Ashfalls
}

\author{
Janet L. Bertog \\ Department of Physics and Geology, Northern Kentucky University, Highland Heights, USA \\ Email: bertogj@nku.edu
}

Received December 26, 2012; revised January 28, 2013; accepted February 18, 2013

Copyright (C) 2013 Janet L. Bertog. This is an open access article distributed under the Creative Commons Attribution License, which permits unrestricted use, distribution, and reproduction in any medium, provided the original work is properly cited.

\begin{abstract}
Strata of the Late Cretaceous Niobrara Formation and Pierre Shale Group include bentonites that provide a distal record of volcanic activity taking place to the west. Detailed stratigraphic analysis combined with mineralogy and geochemistry of the bentonites indicates the following timing of events: 1) Eustatic sea level fall as a result of the end of the Niobrara Cycle; 2) Tectonic deformation of the Western Interior Seaway coincident with tectonism on the Absoroka Thrust in Wyoming and Late Canyon Range Thrust in Utah; 3) Backarc volcanism in Montana associated with the Little Elkhorn Mountain volcanic complex; 4) Forearc volcanism in the Cascades area indicates subduction of a hot oceanic crust where plagioclase in the oceanic crust is being incorporated into the melt; 5) Cessation of tectonic activity results in a return of sedimentation patterns to north-south trending belts with the Boyer Bay and Burning Brule members of the Sharon Springs Formation deposited to the east and the Mitten Black Shale Formation deposited in the basin.
\end{abstract}

Keywords: Pierre Shale; Niobrara Formation; Volcanism; Forearc; Campanian

\section{Introduction}

Strata of the Late Cretaceous Niobrara Formation and Pierre Shale Group (following [1]) dominate the geology of western Kansas and South Dakota. Throughout these strata, numerous bentonite beds indicate the extensive volcanic activity taking place further west. This volcanic activity was a result of subduction of the Farallon Plate along the western margin of North America, which resulted in the formation of a broad north-south trending seaway throughout the western interior of the United States, which was divided into four facies belts [2] - the western foredeep, the western median trough, the eastern median hinge line, and the eastern platform (Figure 1). Of particular importance are the western median trough, the bathymetrically deepest part of the basin; the eastern median hinge line, a narrow tectonically high area; and the eastern platform, a relatively stable area. The transcontinental arch is a Precambrian high that extends from the eastern part of the basin south-southwest across Nebraska and effectively separates the basin into a northern and southern component. During the Campanian, most of the tectonic activity is within the northern part of the basin due to active thrust faulting in Wyoming and Idaho. The Niobrara Formation is limestone and marl deposited during a relatively quiet tectonic interval. Shifting to sili- ciclastic sediments in the Gammon Ferruginous Formation is a result of increased tectonic activity creating a clastic source to the west.

The bentonite beds of the late Cretaceous strata can serve two purposes. First, these beds serve as marker units that can be traced across large geographic areas, providing a mechanism for correlating between localities. Bentonite beds are altered volcanic ash, which is deposited aerially over large areas in a geologically instantaneous time frame. Due to magmatic history, including partial melting, magma mixing, and crystal fractionation, each bentonite can have a unique chemical and mineralogical signature [3]. Despite diagenesis, this signature can be retained in the bentonites. Late Cretaceous bentonite beds have been used for correlation of strata in the lower part of the Pierre Shale Group [4]. The bentonite beds have the potential for correlation at a higher resolution than biostratigraphy or radiometric dating. Within a single ammonite range zone as many as 10 bentonites are present. In addition, correlation can be obtained across facies boundaries, including terrestrial to marine correlations [4]. Because bentonite beds are the result of volcanic activity, the geochemical and mineralogical signatures can be used to further identify the onset of the volcanic activity where the source volcanoes are destroyed or obscured by 
subsequent tectonic activity.

\section{Background}

\subsection{Campanian Stratigraphy of Kansas}

The Campanian stratigraphy of the Western Interior is dominated by the Niobrara Formation with the lower part of the Pierre Shale Group overlying it (Figure 2). Traditionally, the Pierre Shale Group has been referred to as the Pierre Shale Formation and the Sharon Spring Member was described as the lowest member of the formation in Kansas [5,6]. The Sharon Springs Member had been extended to South Dakota, where it was divided into the Gammon Ferruginous Member, the Sharon Springs Member and the Mitten Black Shale Member [7].

The Niobrara Formation was first recognized in Kansas [8] and was divided into the Fort Hayes Limestone and the Smoky Hill Chalk [9-11]. Logan [12] described the units of the Cretaceous of Kansas and Williston [13] described the Smoky Hill Chalk in detail. Hattin [14] recognized numerous marker units in the Smoky Hill Chalk, and established a correlation across Kansas using these marker units, the majority of which were bentonites. Bennett [15] used these marker units as well as one marker unit of Russell [16] to infer stratigraphic position of fossil vertebrates.

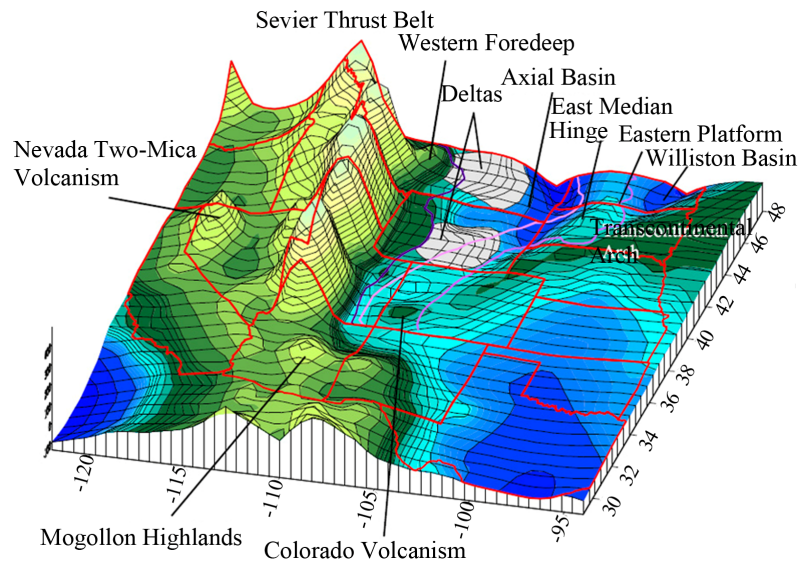

Area shown in the diagram

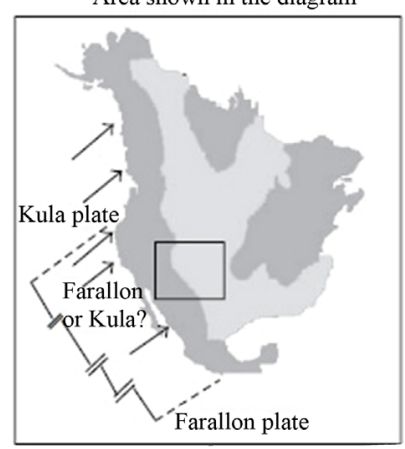

Figure 1. Map of the facies belts of the western interior seaway.
Martin et al. [1] elevated the Pierre Shale to group status and the members to formation status. In South Dakota, the lower part of the Pierre Shale Group includes the Gammon Ferruginous Formation, the Sharon Springs Formation, and the Mitten Black Shale Formation. Bentonite correlation has shown that the Sharon Springs Formation of South Dakota is represented in Kansas by an unconformity at the top of the Gammon Ferruginous Formation [2]. The Gammon Ferruginous Formation is characterized by abundant siderite and limestone concretionary zones, which are more prevalent in South Dakota than in Kansas. Betonites are common in the formation and can be as thick as $0.25 \mathrm{~m}$. The Sharon Springs Formation is restricted to only the most organic rich black shale in South Dakota. The Sharon Springs Formation in the Black Hills is characterized by several thick bentonite beds, reaching up to $1 \mathrm{~m}$ in thickness, the Ardmore bentonite succession [17], which has been used for regional correlation on the basis of stratigraphic position [18], radiometric dating [19], ammonite zonation [7], and geochemical signature [2] (Figure 3).

\subsection{Middle Campanian Volcanism}

In the Campanian, the Farallon Plate was subducting under North America, resulting in extensive volcanism [20] (Figure 4). At ca. 80 Ma the western part of North America had several volcanic centers [21] as a result of the subducting plate changing to a shallower angle, resulting in magmatism along the west coast but also further inland in what is now Colorado, New Mexico and Montana [22,23]. To the west, some magmatic centers continued to be active including calcakaline volcanism in northern British Columbia and in Washington-southern British Columbia [21] as well as northern Nevada [24]. But, Sierran volcanism of California and Nevada came to an end [21] and new magmatic centers arose in Arizona and into New Mexico [25]. Backarc magmatism became active in Colorado and Montana [21] with the largest volcanic center in Montana-the Little Elkhorn Mountains $[21,26]$. This volcanic activity produced extensive ash that was transported aerially across the western interior seaway [27].

Three primary explosive volcanic centers were recognized using bentonite whole-rock rare earth element (REE) analysis: a forearc, volcanic arc, and backarc [3]. A backarc source is characterized by having high light rare earth element (LREE) enrichment and a slight negative europium anomaly, consistent with magma differentiation and continental crustal contamination. Crystallization of plagioclase from the melt incorporates europium, resulting in a depletion of this element relative to other REE in the liquid. LREE are generally incorporated into minerals in the final phases of crystallization (in association with quartz, potassium feldspar, muscovite), resulting 


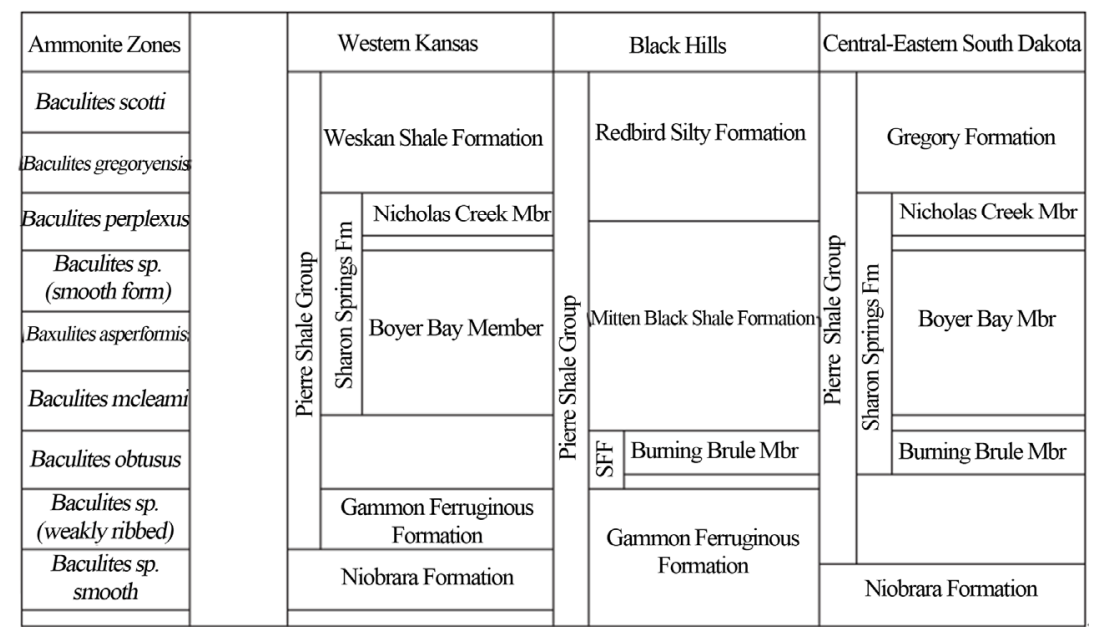

Figure 2. Campanian stratigraphy of Kansas and South Dakota.
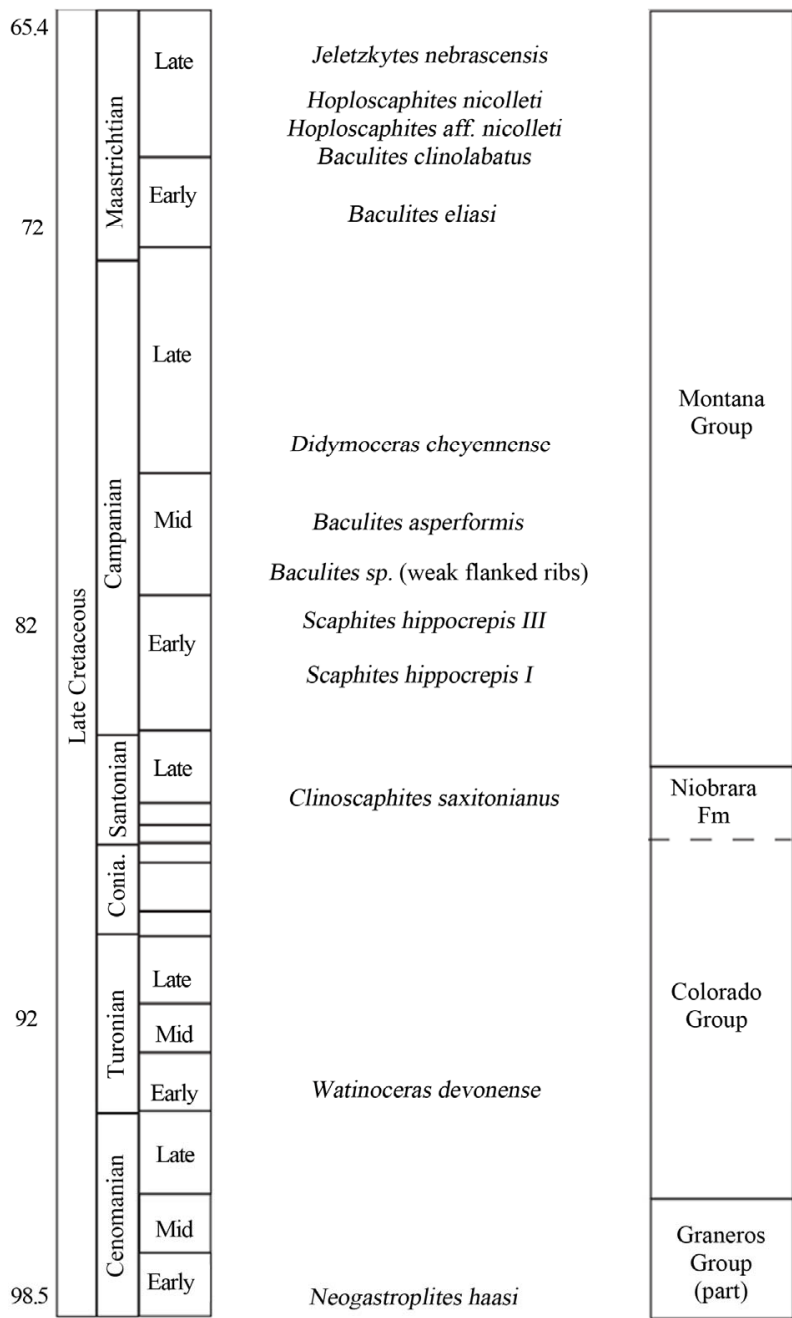

Figure 3. Western Interior Cretaceous stratigraphy, with ammonite zonations, showing the interval of study.

in an increase in these elements [4]. The volcanic arc source is similar to a backarc setting except that fractionation is not as extensive, resulting in lower, but still en- riched, LREE concentrations. A forearc volcanic source is characterized by having a positive europium anomaly, indicating the incorporation of plagioclase into the melt. 
Because plagioclase preferentially incorporates europium during crystallization, melting of plagioclase will increase the europium content relative to other REE in the melt [4]. Plagioclase is in altered basalt of the subducting oceanic crust, and incorporation of plagioclase into the melt suggests melting of the subducting slab. A final volcanic source indicates an anorogenic, dacitic volcanic source that produced localized ash characterized by low $\mathrm{Al}_{2} \mathrm{O}_{3}$ concentrations, reflecting an alkaline source [28].

Bentonites of the Sharon Springs Formation have recorded volcanic activity in all three source areas [4]. Forearc volcanic centers are unusual. The occurrence of this volcanic center in the Sharon Springs Formation has been used to infer that the subduction of the Farallon Plate had reached a point where young oceanic crust was subducting [4]. This is consistent with the angle of subduction getting lower, shifting the other volcanic centers further inland $[22,23]$.

\section{Materials and Methods}

Samples were collected from detailed measured sections of the Niobrara and the lower Pierre Shale Group. The Niobrara Formation was collected from several localities in Kansas (Table 1, Figure 5). However, the Pierre Shale of Kansas has several unconformities, including a critical unconformity that removes the Sharon Springs Formation from the stratigraphy in Kansas [1,4], so samples of the lower Pierre Shale Group were also collected from South Dakota and North Dakota. Detailed measured sections of the Niobrara Formation are provided by Hattin [14] and Bennett et al. [15] and sections of the Pierre Shale Group are provided by Bertog et al. [4].

Samples were collected from fresh bentonite (blue color, [29]). For thin bentonites ( $<10 \mathrm{~cm}$ thick), one sample was collected that covered the full thickness of the bentonites. For thicker bentonites, samples were collected at even intervals throughout the thickness of the bentonite (generally $10 \mathrm{~cm}$ intervals). This method esured comparison between the generally phenocryst-rich base of the bentonite and the phenocryst-poor upper parts of the bentonite. In addition, it allowed for identification of multiple volcanic events that were recorded within a single bentonite as a result of low sedimentation rates between events. In general, bentonites in the field was "clean", free of detrital shale. Where shale was present, care was taken to separate bentonite from shale during collection to ensure that geochemical results represented the bentonite.

Bentonite samples were disaggregated in water using trisodium phosphate and wet-sieving; material between 62.5 and $250 \mu \mathrm{m}$ diameter was retained for further analysis. 150 samples were analyzed for 34 elements using total digestion mass spectroscopy (TD-MS) and instrumental neutron activation analysis (INAA) at Actlabs, Inc. (Appendix 1). Rare earth elements were normalized to chondrite and plotted on chondrite-normalized graphs. Chondrite values are assumed to represent primitive Earth compositions, and deviations from this composition indicate differentiation

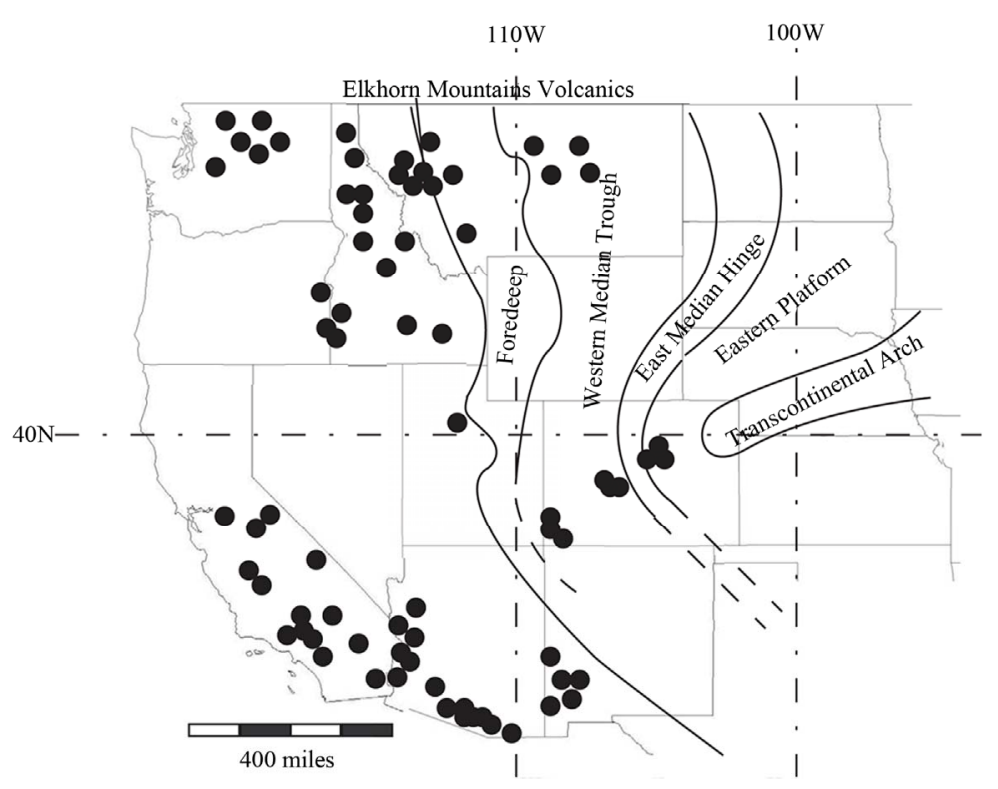

Figure 4. Map of the western United States, showing geographic features during the Campanian. Solid black circles represent volcanic centers that were active (Armstrong and Ward, 1993). In western Montana the Elkhorn Mountains volcanic complex was the most active volcanic center during deposition of the Sharon Springs Formation. Owing to tectonic forces in the west, a shallow interior seaway was formed, which can be divided into four broad tectonic regions: the western foredeep, the western median trough, the eastern median hinge line, and the eastern stable platform. The transcontinental arch separates the northern part of the basin from the southern part. 


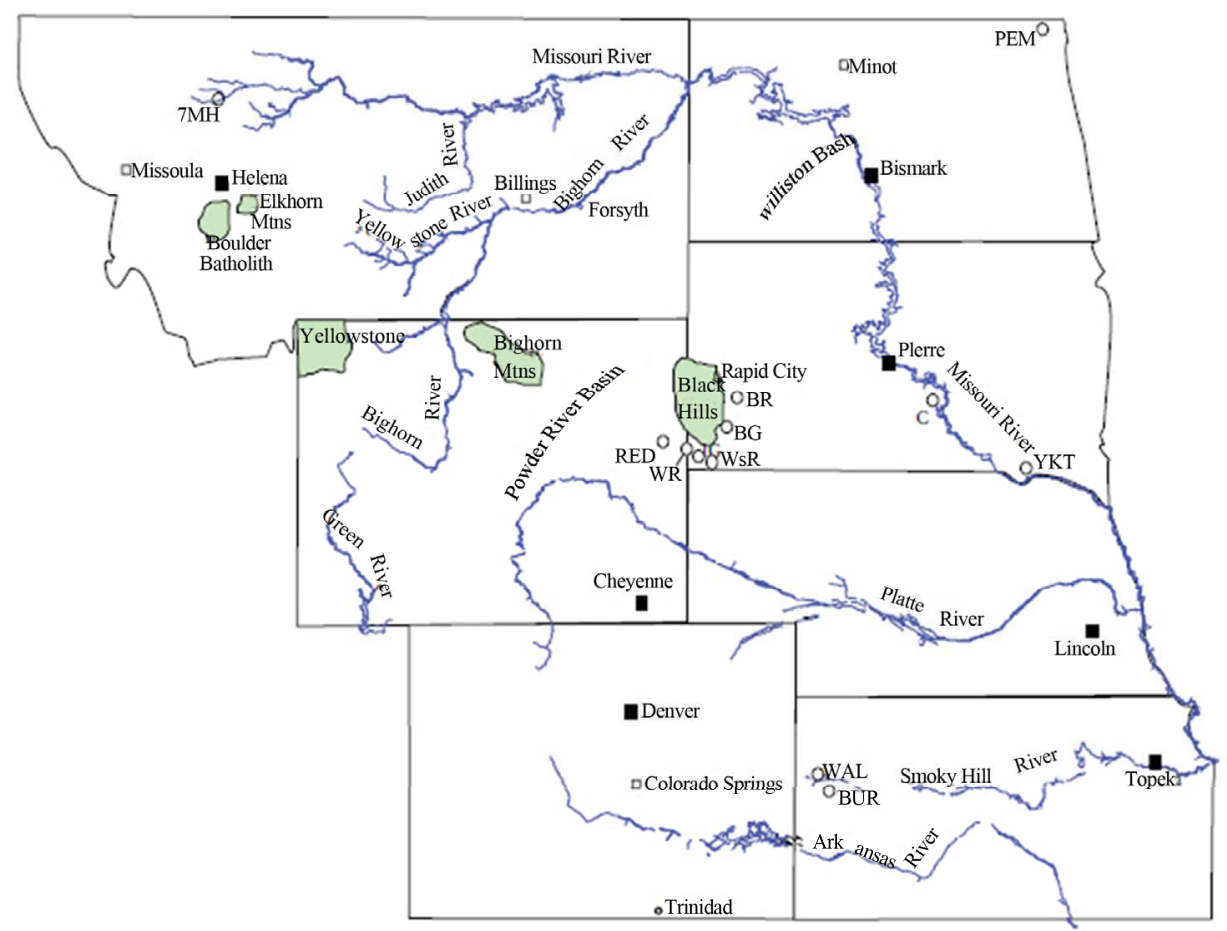

100 miles

Figure 5. Localities of bentonite samples from the Niobrara Formation and lower Pierre Shale Group. Refer to Table 1 for locality abbreviations.

Table 1. Localities of bentonites from the Niobrara Formation and lower Pierre Shale Group.

\begin{tabular}{ccc}
\hline Abb. & Location Name & Map Location \\
\hline RED & $\begin{array}{c}\text { Redbird, Niobrara County, WY } \\
\text { WR }\end{array}$ & $\begin{array}{c}\text { Sec. 13, T38N, R26W } \\
\text { Fall River Ranch, }\end{array}$ \\
WsR & $\begin{array}{c}\text { Wasserburger Ranch, } \\
\text { Fall River City, SD }\end{array}$ & Sec. 27, T1S, R1E \\
BG & Buffalo Gap, Custer County, SD & Sec. 31, T7S, R7E \\
BR & Brown Ranch, Custer County, SD & Sec. 30, R2S, R87E \\
C & Missouri River, & Sec. 9, T102N, R71W \\
WAL & $\begin{array}{c}\text { Mrule County, SD } \\
\text { Logan County, KS }\end{array}$ & Sec. 13, T12S, R37W \\
BUR & Burris Draw, Logan County, KS & Sec. 9, T15S, R32W \\
CR & Castle Rock, Gove County, KS & Sec. 1, T14S, R26W \\
Loc 20 & Bennett Loc 20, & Sec. 1, T15S, R33W \\
Loc 21 & $\begin{array}{c}\text { Bogan County, KS } \\
\text { Logan County, KS }\end{array}$ & Sec. 26, T14S, R33W \\
Loc 24 & Bennett Loc 24, & Sec. 23, T13S, R34W \\
\hline
\end{tabular}

of the magma.

In addition to whole rock analysis, bentonites were analyzed for the phenocryst composition (Appendix 2). This provided information for bentonites of the Pierre Shale Group, but bentonites of the Niobrara Formation had few phenocrysts. Samples were sieved using 62.5 and $250 \mu \mathrm{m}$ sieves. The material that was $<62.5 \mu \mathrm{m}$ was allowed to settle for $2 \mathrm{~h}$ so that only the clay-sized fraction, $<2 \mu \mathrm{m}$, remained in suspension. Oriented slides were prepared using the pipette method. Samples were analyzed by powder X-ray diffraction using a Rigaku Ultima III X-ray diffractometer of the samples under air-dried, glycollated, and heated conditions. Samples were run from $2 \theta$ to $32 \theta$ with a step size of $0.05 \theta$ a count time of $2 \mathrm{~s}$. Phenocrysts between 62.5 and $250 \mu \mathrm{m}$ were kept for analysis.

\section{Results}

\subsection{Bentonite Fingerprinting}

Fingerprinting bentonites can be useful for widespread correlation through the use of unique characteristics used to identify a layer anywhere that it is deposited. For this to be successful, the characters must be variable between volcanic eruptions, must be impervious to the depositional environment, and must be independent of diagenesis.

Multiple techniques are used to provide a comprehensive fingerprint for each layer because individual methods of bentonite characterization may not provide a 
unique fingerprint. For example, the REE patterns in bentonites are a result of the source region and may be similar for more than one bentonite. The phenocrysts, however, may be different between layers with the same REE. This is because phenocryst composition is related to magma composition at the time of eruption. Therefore, a combination of REE with phenocryst composition can be used to identify individual layers.

Bertog et al. [4] used a combination of REE, phenocryst composition and chemistry, and stratigraphic position to identify groups of bentonites in the Sharon Springs Formation. The bentonites were divided four groups, which are used here.

\subsection{Whole Rock Geochemistry}

Bentonites were identified using discriminant function analysis, which uses multivariant functions to distinguish statistically unique groups. The bentonites separated into four groups with these functions calculated (Figure 6):

$$
\begin{aligned}
\text { Function } 1= & 13.799+0.109^{*} \mathrm{La}-0.265^{*} \mathrm{Ce} \\
& -0.002^{*} \mathrm{Nd}+0.632^{*} \mathrm{Sm} \\
& +0.925^{*} \mathrm{Eu}-1.336^{*} \mathrm{~Tb}-0.505^{*} \mathrm{Yb} \\
& -0.194^{*} \mathrm{Lu}+3.747^{*} \mathrm{Eu} / \mathrm{Eu}^{*}
\end{aligned}
$$

Function $2=21.366+0.069^{*} \mathrm{Lu}-0.193^{*} \mathrm{Ce}$

$$
\begin{aligned}
& +0.192^{*} \mathrm{Nd}-0.322^{*} \mathrm{Sm}+2.58^{*} \mathrm{Eu} \\
& -0.0773^{*} \mathrm{~Tb}+1.131^{*} \mathrm{Yb}+19.857^{*} \mathrm{Eu} / \mathrm{Eu}^{*}
\end{aligned}
$$

${ }^{*} \mathrm{Eu} / \mathrm{Eu}^{*}=\left[\mathrm{Eu} /\left(\mathrm{Sm}^{*} \mathrm{~Tb}\right)^{*} 0.5\right]$. If $\mathrm{Tb}$ was below detection limits, $\mathrm{Yb}$ was used in the calculation.

Discriminant function analysis provides a statistical means for segregating bentonite groups but does not provide for interpretation of source regions for the four groups distinguished using discriminant function analysis. In order to determine source regions, the data were plotted on REE spider diagrams and compared to known volcanic sources (as described above). WR Group 1 and 4 plot with high LREE ( $\sim 100 \mathrm{ppm}$ La) and HREE of about $10-20 \mathrm{ppm}$. This group plots favorably with a backarc volcanic setting. WR Group 2 has minor LREE enrichment (10 - $100 \mathrm{ppm} \mathrm{La)} \mathrm{and} \mathrm{low} \mathrm{HRR} \mathrm{(1} \mathrm{-} 20$ ppm). WR Group 3 has low REE but is characterized by a positive Eu anomaly (Figure 7).

\subsection{Phenocryst Analysis}

Primary volcanogenic phenocrysts are present in many of the bentonites in the Gammon Ferruginous and Sharon Springs Formation. Bentonites of the Sharon Springs Formation were divided into two groups - rhyolite and dacite - based on their composition of quartz-potassium feldspar-plagioclase (Figure 8). Bentonites of the Niobrara Formation were heavily altered, even where the surrounding limestone was fresh. In the field these bentonites were difficult to distinguish as bentonites, but consistently had gypsum and limonite as weathering products. Because of this, it was difficult to obtain phenolcrysts that were useful for interpretation. Phenocrysts that were available were primarily quartz with minor biotite and feldspar.

Bentonites of the Gammon Ferruginous Formation plot as rhyolite based on their ratio of quartz-potassium feldspar-plagioclase (30\% - 50\% quartz, $10 \%-30 \%$ plagioclase and $40 \%-60 \%$ potassium feldspar). These bentonites plot favorably with WR Group 2 of the Sharon Springs Formation (Figure 8).

\section{Discussion}

The Late Cretaceous (Campanian) strata of the Western Interior Seaway of North America were deposited during a complex time when tectonic activity and eustatic sea level changes overlapped. The stratigraphic record of the Niobrara, Gammon Ferruginous and Sharon Springs

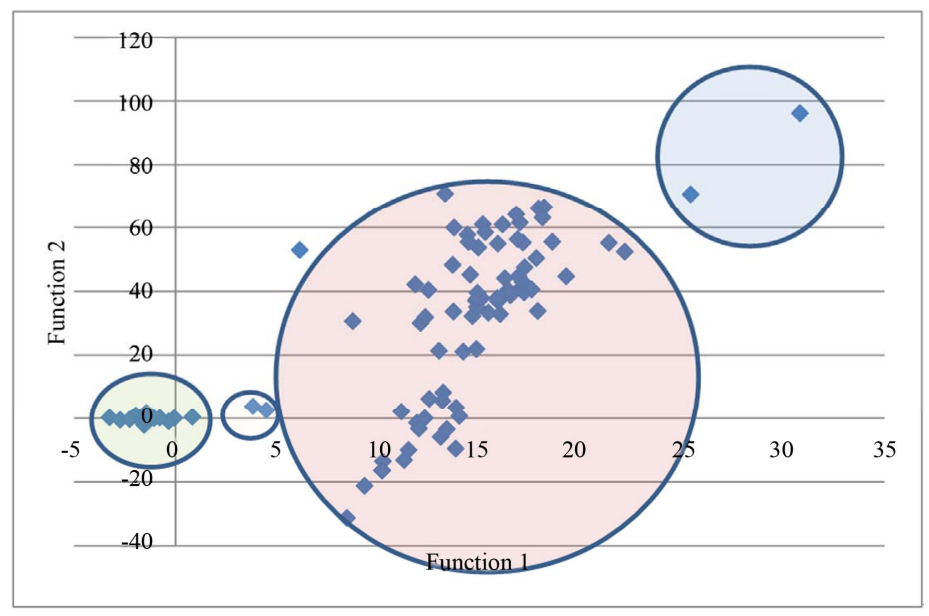

Figure 6. Discriminant function analysis combines multiple parameters to distinguish groups within a data set. Based on discriminant function analysis, functions produced four separate groups. 


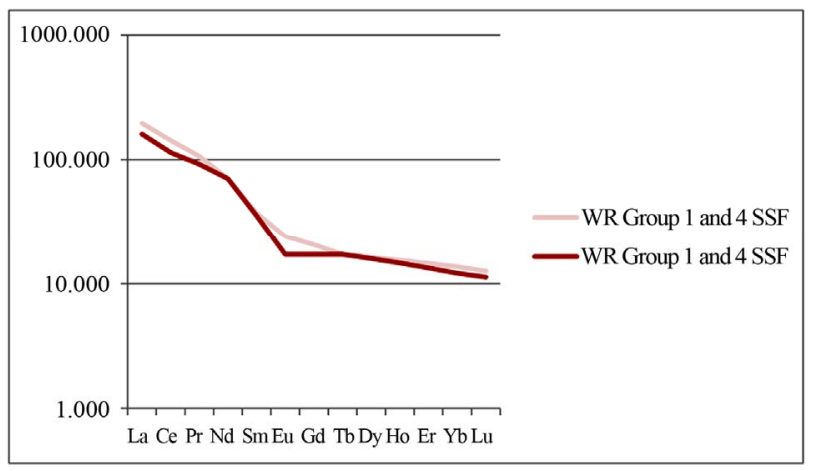

(a)

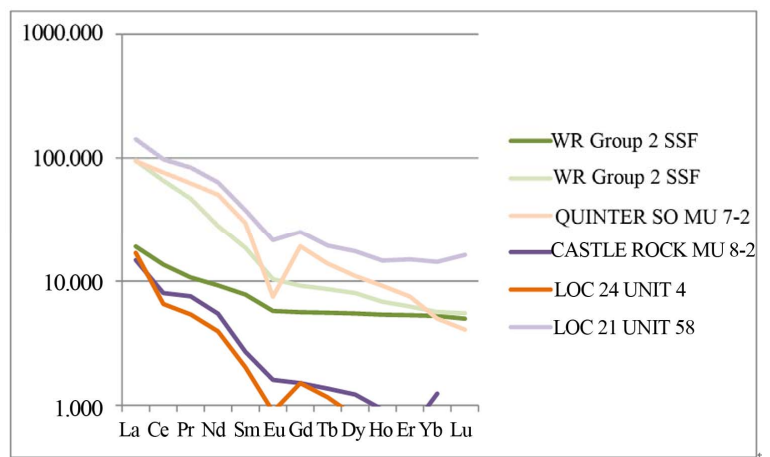

(b)

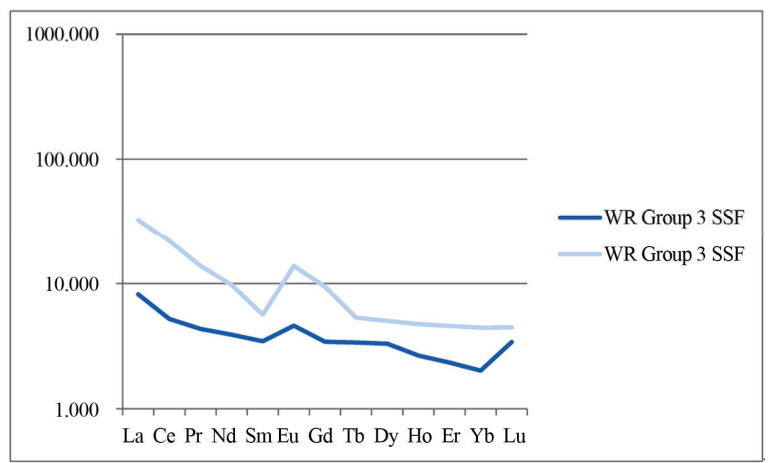

(c)

Figure 7. Whole rock REE analysis of the bentonites can be divided into three major categories on the basis of the REE distribution in spider diagrams. (a) Bentonites of WR Group 2 (from Bertog et al., 2007) and bentonites of the Niobrara and Gammon Ferruginous formations represent a volcanic arc setting. Two groups can be distinguished-those with a strong negative Eu anomaly and those with a minor negative Eu anomaly; (b) Bentonites of WR Groups 1 and 4 (from Bertog et al., 2007) in the Sharon Springs Formation represent a backarc volcanic setting; (c) Bentonites of WR Group 3 (from Bertog et al., 2007) in the Sharon Springs Formation represent a forearc volcanic setting.

formations, records this complex interaction at resolution higher than structural geology and petrology could. Each individual unit of the stratigraphic record indicates a unique event in time and relative timing of each event is clearly laid out like pages of a book. The carbonate Niobrara Formation gave way to the Gammon Ferruginous Formation as a result primarily of tectonic activity to the west. Nearly synchronous with this sedimentological change, increased volcanic activity and thrusting in the west was taking place and global sea levels were rising. Based on stratigraphic interpretation, the events that took place within this interval included: 1) Occurrence of a clastic source with deposition of the Gammon Ferruginous Formation; 2) Onset of tectonic activity and thrusting to the west as indicated by two stratigraphic cycles in the Burning Brule Member of the Pierre Shale [30]; 3) Backarc volcanism recorded by bentonites of the Ardmore bentonite succession in the Burning Brule Member of the Sharon Springs Formation (Bertog et al., 2007); 4) Forearc volcanism recorded by thin bentonites near the top of the Sharon Springs Formation [4].

Eustatic cycles are represented by in the sediments of the Late Cretaceous Western Interior by north-south trending facies belts, such as the Gammon Ferruginous Formation in the regressive phase of the Niobrara Cycle. These belts are separated by their position in the foreland basin. During the highstand systems tract of the Niobrara Formation, the Gammon Ferruginous Member was deposited in the foreland basin while erosion was occurring on the eastern stable platform.

Following the Gammon Ferruginous Formation, deposition of the Burning Brule Member of the Pierre Shale represents a tectonic sequence, corresponding to tectonic activity on the Absoroka Thrust in Wyoming and the Late Canyon Range Thrust in Utah [30]. This tectonic phase is coincident with changes in the subduction pattern along the western margin. Subduction rates increased, as evidenced by the formation of a peripheral bulge in the Western Interior Seaway and recorded as an unconformity at the base of the Burning Brule Member [30]. Nearly coincident with the formation of this peripheral bulge, the Ardmore bentonite succession was deposited. This thick succession of bentonites records extensive volcanism throughout the west. Most of this volcanism took place in a backarc setting in Montana [4]. The occurrence of this backarc volcanism is a result of a 

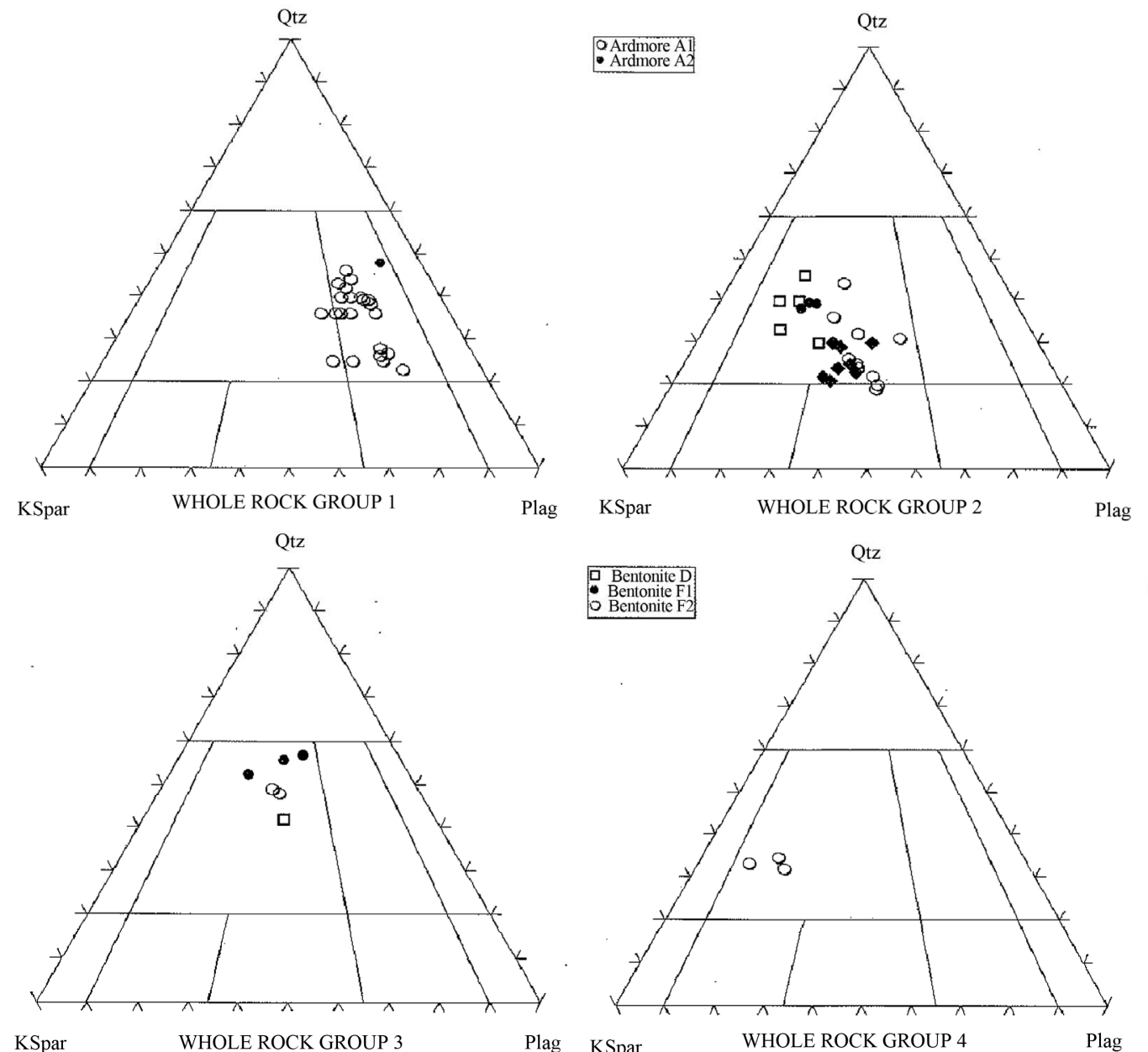

Figure 8. Based on the distribution of light phenocrysts, and plotted on a QAF (quartz-alkali feldspar-potassium feldspar) diagram, bentonites can be classified as rhyolites and dacites. Bentonites of WR group 1 (see Figure 4) are dacites, while bentonites from WR Groups 2-4 are rhyolites.

decrease in the angle of subduction along the west coast. The Burning Brule Member is deposited in two stratigraphic sequences that correspond to migration of the peripheral bulge across the basin [30]. During the deposition of the Burning Brule Member, sedimentation patterns changed so that the Burning Brule Formation is deposited north of Nebraska while an unconformity was forming south of Nebraska. This change in sedimentation patterns is a direct result of tectonic activity in the northern part of the basin while the southern part of the basin remained stable.

It is not until near the top of the Burning Brule Member that we see evidence of the forearc volcanism [4]. Forearc volcanism is a result of subduction of a young oceanic crust, which is still relatively hot. This causes the oceanic crust to melt as it subducts and plagioclase from the oceanic crust is incorporated into the magma, as evidenced by the increase in Eu.

Following deposition of the Burning Brule Member, the sedimentation patterns returned to north-south trend- ing belts. In the basin the Mitten Black Shale Formation was deposited while further to the east the Nicholas Creek and Boyer Bay members of the Sharon Springs Formation were deposited.

\section{Summary}

The sequence of tectonic and eustatic events in the Campanian of North America are discerned through stratigraphic interpretation of the Niobrara and Sharon Springs formations. These events include:

Eustatic sea level fall as a result of the end of the Niobrara Cycle. Volcanic activity during this time was entirely volcanic arc in nature.

Tectonic deformation of the Western Interior Seaway coincident with tectonism on the Absoroka Thrust in Wyoming and Late Canyon Range Thrust in Utah resulted in differentiation between the northern part of the seaway and the southern part of the seaway, including the formation of a distinct peripheral bulge in the north- 
ern part of the seaway.

Backarc volcanism in Montana associated with the Little Elkhorn Mountain volcanic complex deposits bentonites within the Ardmore bentonite succession. The formation of this volcanic complex further inland than previous volcanism indicates a more shallow subduction angle of the Farallon Plate. Volcanic arc volcanism also continued through this time.

Forearc volcanism in the Cascades area indicates subduction of a hot oceanic crust where plagioclase in the oceanic crust is being incorporated into the melt. Volcanic arc volcanism continued through this time.

Cessation of tectonic activity results in a return of sedimentation patterns to north-south trending belts with the Boyer Bay and Burning Brule members deposited to the east and the Mitten Black Shale Formation deposited in the basin.

\section{Acknowledgements}

Funding for this research was provided in part by the Northern Kentucky University Center for Integrated Science and Mathematics (CINSAM) and the Northern Kentucky University Faculty Senate Sabbatical Program. Michael Everhart was very helpful in locating outcrops with marker units described by Hattin and Bennett. Desiree Nichols and Evan Draper were student researchers on this project. In memory of Evan Draper who participated as an undergraduate in the research on the Niobrara Formation in this paper and Jeff VonLoh, a close friend and colleague who participated in the field work on the Pierre Shale Group.

\section{REFERENCES}

[1] J. E. Martin, J. L. Bertog and D. C. Parris, "Revised Lithostratigraphy of the Lower Pierre Shale Group (Campanian) of Central South Dakota, including Newly Designated Members," In: J. E. Martin and D. C. Parris, Eds., The Geology and Paleontology of the Late Cretaceous Marine Deposits of the Dakotas. Geological Society of America Special Paper, Vol. 427, 2007, pp. 9-22.

[2] P. G. DeCelles, "Late Cretaceous-Paleocene Synorogenic Sedimentation and Kinematic History of the Sevier Thrust Belt, Northeast Utah and Southwest Wyoming," Geological Society of America Bulletin, Vol. 106, No. 1, 1994, pp. 32-56.

[3] Y. Tatsumi and S. Eggins, "Subduction Zone Magmatism," Blackwell Science, Cambridge, 1995.

[4] J. L. Bertog, W. D. Huff and J. E. Martin, "Geochemical and Mineralogical Recognition of the Bentonites in the Lower Pierre Shale Group and Their Use in Regional Stratigraphic Correlation," In: J. E. Martin and D. C. Parris, Eds., The Geology and Paleontology of the Late Cretaceous Marine Deposits of the Dakotas, Geological Society of America Special Paper, Vol. 427, 2007, pp.
23-50.

[5] M. K. Elias, "The Geology of Wallace County Kansas," Kansas Geological Survey Bulletin, Vol. 18, 1993, p. 254.

[6] J. R. Gill, W. A. Cobban and L. G. Schultz, "Stratigraphy and Composition of the Sharon Springs Member of the Pierre Shale in Western Kansas: US Geological Survey Professional Paper 728," 1972.

[7] J. R. Gill and W. A. Cobban, "The Redbird Section of the Upper Cretaceous Pierre Shale in Wyoming. US Geological Survey Professional Paper 393-A: A-1-A73," 1966.

[8] B. F. Mudge, "First Annual Report on the Geology of Kansas," Lawrence, Kansas, 1666.

[9] B. F. Mudge, "Notes on the Tertiary and Cretaceous Periods of Kansas," US Geological and Geographical Survey of the Territories Bulletin, Vol. 2, 1876, pp. 211-221.

[10] S. W. Williston, "The Niobrara Cretaceous of Western Kansas," Transactions of the Kansas Academy of Science, Vol. 13, 1893, pp. 107-111.

[11] F. W. Cragin, "On the Stratigraphy of the Platte series, or Upper Cretaceous of the Plains," Colorado College Studies, Vol. 6, 1896, pp. 49-52.

[12] W. N. Logan, "The Upper Cretaceous of Kansas, with an Introduction by Erasmus Haworth," Kansas University Geological Survey, Vol. 2, 1897, pp. 195-234.

[13] S. W. Williston, "The Kansas Niobrara Cretaceous," Kansas University Geological Survey, Vol. 2, 1897, pp. 235246.

[14] D. E. Hattin, "Stratigraphy and Depositional Environment of Smoky Hill Chalk Member, Niobrara Chalk (Upper Cretaceous) of the Type Area, Western Kansas," Kansas Geological Survey Bulletin, Vol. 225, 1982, 108 p.

[15] S. C. Bennett, "Inferring Stratigraphic Position of Fossil Vertebrates from the Niobrara Chalk of Western Kansas," 1990.

[16] W. L. Russell, "Stratigraphy and Structure of the Smoky Hill Chalk in Western Kansas," American Association of Petroleum Geologists, Bulletin, Vol. 13, No. 6, 1929, pp. 595-604.

[17] R. C. Spivey, "Bentonite in Southwestern South Dakota. South Dakota Geological Survey Report of Investigations," 1940.

[18] T. S. Dyman, et al., "Stratigraphic Transects for Cretaceous Rocks, Rocky Mountains and Great Plains Regions," In: M. V. Caputo, J. A. Peterson and K. J. Franczyk, Eds., Mesozoic Systems of the Rocky Mountain Region, Rocky Mountain Section SEPM, Denver, 1994, pp. 365-392.

[19] J. D. Obradovich, “A Cretaceous Time Scale," In: W. G. E. Caldwell and E. G. Kaufman, Eds., Evolution of the Western Interior Basin, Geological Association of Canada, St. John's, Newfoundland, 1993, pp. 379-396.

[20] J. W. H. Monger, "Cretaceous Tectonics of the North American Cordillera," In: W. G. E. Caldwell and E. G. Kauffman, Eds., Evolution of the Western Interior Basin, Geological Association of Canada, St. John's, Newfoundland, 1993, pp. 31-48.

[21] R. L. Armstrong and P. Ward, "Late Triassic to Earliest Eo- 
cene Magmatism in the North American Cordillera: Implications for the Western Interior Basin," In: W. G. E. Caldwell and E. G. Kauffman, Eds., Evolution of the Western Interior Basin, Geological Association of Canada, St. John's, Newfoundland, 1993, pp. 49-72.

[22] T. A. Cross and R. H. Pilger Jr., "Tectonic Controls of Late Cretaceous Sedimentation, Western Interior, USA," $\mathrm{Na}$ ture, Vol. 274, No. 5672, 1978, pp. 653-657. doi:10.1038/274653a0

[23] W. R. Dickinson, "Plate Tectonic Evolution of the Southern Cordillera," In: W. R. Dickinson and W. D. Payne, Eds., Relations of Tectonics to Ore Deposits in the Southern Cordillera, Arizona Geological Society Digest, Vol. 13, 1981, pp. 113-135.

[24] P. G. Vikre and E. H. McKee, "Zoning and Chronology of Hydrothermal Events in the Humboldt Range," 1985.

[25] P. J. Coney and S. J. Reynolds, "Cordilleran Benioff Zones," Nature, Vol. 270, No. 5636, 1977, pp. 403-406. doi: $10.1038 / 270403 \mathrm{a} 0$

[26] G. D. Robinson, M. R. Klepper and J. D. Obradovich, "Overlapping Plutonism, Volcanism and Tectonism in the Boulder Batholith Region, Western Montana," Geologi- cal Society of America Memoir, Vol. 116, 1968, pp. $557-$ 576.

[27] E. H. Christensen, B. J. Kowallis and M. D. Barton, "Temporal and Spatial Distribution of Volcanic Ash in Mesozoic Sedimentary Rocks of the Western Interior: An Alternative Record of Mesozoic Magmatism," In: M. V. Caputo, et al., Eds., Mesozoic Systems of the Rocky Mountain Region, Society for Sedimentary Geology (SEPM), Rocky Mountain Section, 1994, pp. 73-94.

[28] A.-F. M. Adbel-Rahman, "Discussion on the Comment on Nature of Biotites in Alkaline, Calc-Alkaline and Peraluminous Magmas," Journal of Petrology, Vol. 37, No. 5, 1996, pp. 1031-1035. doi:10.1093/petrology/37.5.1031

[29] J. M. Elzea and H. H. Murray, "Variation in the Mineralogical, Chemical and Physical Properties of the Cretaceous Clay Spur Bentonite in Wyoming and Montana (USA)," Applied Clay Science, Vol. 5, No. 5, 1990, pp. 229-248.

[30] J. L. Bertog, "Stratigraphy of the Lower Pierre Shale (Campanian): Implications for the Tectonic and Eustatic Controls on Facies Distributions," Journal of Geological Research, Vol. 2010, 2010, 15 p. 
Appendix 1. Whole-rock rare earth element analyses of bentonite samples, niobrara formation.

\begin{tabular}{|c|c|c|c|c|c|c|c|c|c|c|c|c|c|}
\hline & $\mathrm{La}$ & $\mathrm{Ce}$ & $\operatorname{Pr}$ & $\mathrm{Nd}$ & $\mathrm{Sm}$ & $\mathrm{Eu}$ & $\mathrm{Gd}$ & $\mathrm{Tb}$ & Dy & Ho & $\mathrm{Er}$ & $\mathrm{Yb}$ & $\mathrm{Lu}$ \\
\hline $\begin{array}{l}\text { FORT HAYS } \\
\text { L FH } 1-1\end{array}$ & 94.09283 & 57.74878 & 54.9569 & 44.42013 & 26.35135 & 14.74245 & 20.60302 & 13.85042 & 13.00813 & 10.98901 & 10.625 & 8.074534 & 8.130081 \\
\hline $\begin{array}{l}\text { FORT HAYS } \\
\text { L FH } 1 \text { - } 2\end{array}$ & 108.8608 & 69.49429 & 65.73276 & 50.32823 & 29.72973 & 16.34103 & 23.61809 & 16.6205 & 14.63415 & 12.82051 & 11.25 & 8.695652 & 8.130081 \\
\hline $\begin{array}{c}\text { FORT HAYS } \\
\text { L FH } 1 \text { - } 3\end{array}$ & 124.8945 & 78.30343 & 78.66379 & 61.70678 & 36.48649 & 19.36057 & 26.63317 & 19.39058 & 16.26016 & 12.82051 & 11.875 & 8.695652 & 8.130081 \\
\hline $\begin{array}{c}\text { FORT HAYS } \\
\text { L FH } 1 \text { - } 4\end{array}$ & 89.87342 & 53.01794 & 53.87931 & 43.98249 & 27.7027 & 15.80817 & 21.10553 & 16.6205 & 13.41463 & 12.82051 & 10.625 & 8.074534 & 8.130081 \\
\hline $\begin{array}{l}\text { FORT HAYS } \\
\text { L FH } 1 \text { - } 5\end{array}$ & 81.4346 & 52.69168 & 50.64655 & 38.73085 & 22.2973 & 11.72291 & 15.57789 & 11.08033 & 10.1626 & 9.157509 & 8.125 & 6.21118 & 4.065041 \\
\hline $\begin{array}{l}\text { FORT HAYS } \\
\text { L FH } 1-6\end{array}$ & 73.41772 & 39.64111 & 42.02586 & 33.91685 & 20.94595 & 12.07815 & 15.57789 & 11.08033 & 10.1626 & 9.157509 & 8.125 & 6.21118 & 8.130081 \\
\hline $\begin{array}{c}\text { FORT HAYS } \\
\text { L FH } 1-7\end{array}$ & 86.91983 & 51.22349 & 51.72414 & 40.70022 & 23.64865 & 13.14387 & 17.08543 & 13.85042 & 10.56911 & 9.157509 & 8.125 & 6.21118 & 8.130081 \\
\hline $\begin{array}{c}\text { FORT HAYS } \\
\text { L FH } 1-8\end{array}$ & 123.2068 & 81.07667 & 79.74138 & 64.3326 & 38.51351 & 19.71581 & 28.64322 & 19.39058 & 16.26016 & 14.65201 & 13.125 & 9.31677 & 8.130081 \\
\hline $\begin{array}{l}\text { FORT HAYS } \\
\text { L FH } 1 \text { - } 9\end{array}$ & 45.99156 & 43.06688 & 38.7931 & 32.82276 & 18.91892 & 4.440497 & 12.56281 & 8.310249 & 5.691057 & 5.494505 & 3.75 & 2.484472 & \\
\hline $\begin{array}{l}\text { FORT HAYS } \\
\text { L FH } 1-10\end{array}$ & 108.0169 & 83.52365 & 75.43103 & 59.95624 & 36.48649 & 17.93961 & 24.62312 & 16.6205 & 14.22764 & 10.98901 & 10.625 & 8.695652 & 8.130081 \\
\hline $\begin{array}{l}\text { FORT HAYS } \\
\text { L FH 1-11 }\end{array}$ & 72.99578 & 51.38662 & 45.25862 & 35.22976 & 20.94595 & 11.90053 & 15.07538 & 11.08033 & 9.756098 & 9.157509 & 8.125 & 6.832298 & 8.130081 \\
\hline $\begin{array}{l}\text { FORT HAYS L } \\
\text { FH } 1-12\end{array}$ & 75.10549 & 38.66232 & 43.10345 & 34.13567 & 20.94595 & 12.96625 & 17.08543 & 13.85042 & 12.19512 & 10.98901 & 10 & 8.074534 & 8.130081 \\
\hline $\begin{array}{l}\text { FORT HAYS } \\
\text { L FH } 1 \text { - } 13\end{array}$ & 106.7511 & 64.76346 & 63.57759 & 47.92123 & 27.7027 & 15.63055 & 20.1005 & 13.85042 & 13.00813 & 10.98901 & 10.625 & 8.695652 & 8.130081 \\
\hline $\begin{array}{l}\text { FORT HAYS } \\
\text { L FH } 1 \text { - } 14\end{array}$ & 102.9536 & 54.323 & 58.18966 & 46.82713 & 28.37838 & 15.98579 & 22.11055 & 16.6205 & 14.63415 & 12.82051 & 12.5 & 9.937888 & 8.130081 \\
\hline $\begin{array}{l}\text { FORT HAYS } \\
\text { L FH } 1 \text { - } 15\end{array}$ & 92.40506 & 68.35237 & 63.57759 & 49.23414 & 28.37838 & 14.20959 & 18.59296 & 13.85042 & 10.56911 & 9.157509 & 7.5 & 5.590062 & 4.065041 \\
\hline $\begin{array}{l}\text { QUINTER } \\
\text { SO MU } 2\end{array}$ & 40.08439 & 32.78956 & 23.7069 & 16.6302 & 8.108108 & 4.440497 & 5.025126 & 2.770083 & 3.252033 & 1.831502 & 2.5 & 2.484472 & \\
\hline $\begin{array}{l}\text { QUINTER } \\
\text { SO MU } 4\end{array}$ & 49.36709 & 43.39315 & 35.56034 & 26.69584 & 14.86486 & 7.460036 & 9.547739 & 5.540166 & 5.284553 & 3.663004 & 3.75 & 3.10559 & \\
\hline $\begin{array}{l}\text { QUINTER } \\
\text { SO MU } 5\end{array}$ & 16.4557 & 11.58238 & 8.62069 & 6.126915 & 3.378378 & 1.776199 & 2.512563 & & 1.626016 & & 1.875 & 1.863354 & \\
\hline $\begin{array}{c}\text { QUINTER } \\
\text { SO MU } 7 \text { - } 1\end{array}$ & 87.34177 & 63.29527 & 51.72414 & 40.70022 & 21.62162 & 5.506217 & 13.56784 & 8.310249 & 6.910569 & 5.494505 & 4.375 & 3.10559 & \\
\hline $\begin{array}{c}\text { QUINTER } \\
\text { SO MU } 7 \text { - } 2\end{array}$ & 94.51477 & 76.50897 & 62.5 & 50.54705 & 29.72973 & 7.460036 & 19.09548 & 13.85042 & 10.97561 & 9.157509 & 7.5 & 4.968944 & 4.065041 \\
\hline $\begin{array}{c}\text { CASTLE ROCK } \\
\text { MU } 8-1\end{array}$ & 18.98734 & 9.461664 & 7.543103 & 5.251641 & 2.702703 & 1.065719 & 2.01005 & & 1.219512 & & 1.25 & 1.242236 & \\
\hline $\begin{array}{c}\text { CASTLE ROCK } \\
\text { MU } 8-2\end{array}$ & 14.76793 & 7.993475 & 7.543103 & 5.47046 & 2.702703 & 1.598579 & 1.507538 & & 1.219512 & & 0.625 & 1.242236 & \\
\hline $\begin{array}{c}\text { CASTLE ROCK } \\
\text { MU } 8-3\end{array}$ & 1.687764 & 0.815661 & & 0.437637 & & & & & & & & & \\
\hline $\begin{array}{c}\text { CASTLE ROCK } \\
\text { MU } 9-1\end{array}$ & 16.87764 & 12.56117 & 10.77586 & 8.752735 & 5.405405 & 2.309059 & 3.517588 & 2.770083 & 2.845528 & 1.831502 & 2.5 & 2.484472 & \\
\hline $\begin{array}{c}\text { CASTLE ROCK } \\
\text { MU } 9-2\end{array}$ & 57.38397 & 41.27243 & 34.48276 & 25.38293 & 14.86486 & 6.571936 & 9.547739 & 8.310249 & 6.910569 & 5.494505 & 5.625 & 5.590062 & 4.065041 \\
\hline $\begin{array}{l}\text { CASTLE ROCK } \\
\text { MU } 10-1\end{array}$ & 5.485232 & 3.915171 & 3.232759 & 2.407002 & 1.351351 & & 1.005025 & & 0.406504 & & & & \\
\hline $\begin{array}{c}\text { CASTLE ROCK } \\
\text { MU } 10-2\end{array}$ & 4.64135 & 3.752039 & 3.232759 & 2.407002 & 1.351351 & & 1.005025 & & 0.813008 & & 0.625 & 0.621118 & \\
\hline
\end{tabular}




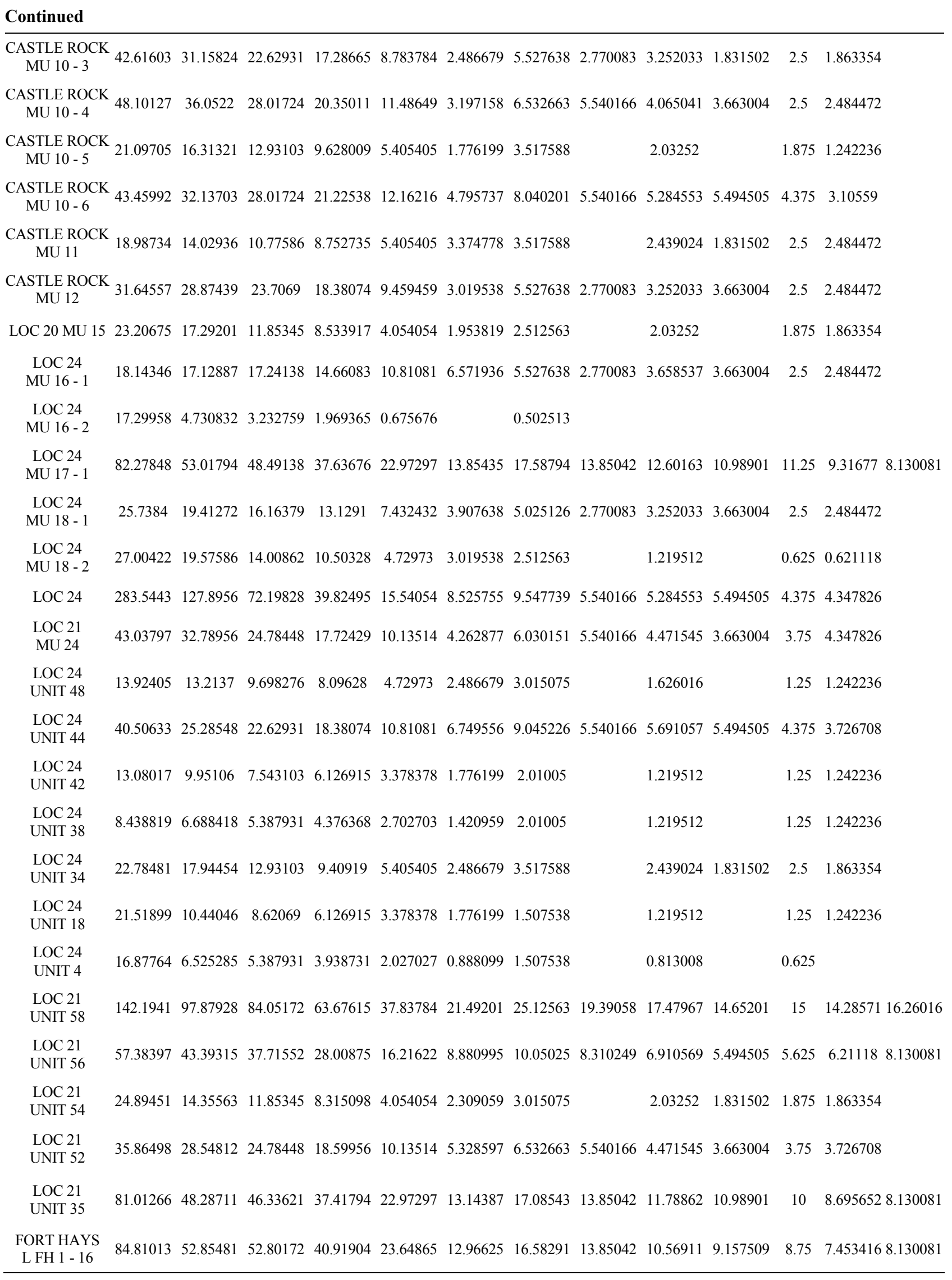


Appendix 2. Point counts of the light mineral fraction of bentonites, gammon ferruginous member.

\begin{tabular}{|c|c|c|c|}
\hline & K-feldspar & Quartz & Plagioclase \\
\hline IG1-99-1 & 8 & 27 & 15 \\
\hline BG1 & 13 & 25 & 12 \\
\hline PEM1-4 & 6 & 40 & 54 \\
\hline PEM1-5 & 24 & 20 & 58 \\
\hline Pem1-6 & 22 & 22 & 56 \\
\hline PEM1-7 & 20 & 20 & 60 \\
\hline RED1-3 & 25 & 22 & 3 \\
\hline RED1-4 & 37 & 9 & 4 \\
\hline RED1-7 & 25 & 13 & 2 \\
\hline RED1-8 & 44 & 4 & 2 \\
\hline RED1-9 & 46 & 30 & 14 \\
\hline RED1-10 & 40 & 46 & 14 \\
\hline WAL1-B8 & 0 & 40 & 0 \\
\hline WAL2-B2 & 14 & 18 & 4 \\
\hline WAL3-B1 & 0 & 16 & 0 \\
\hline WR20 & 44 & 40 & 16 \\
\hline WR23 & 48 & 40 & 12 \\
\hline WR24 & 45 & 30 & 25 \\
\hline
\end{tabular}

